\title{
US - Iran Proxy War in Middle East Under Trump Administration
}

\author{
Hino Samuel Jose $1^{1 *}$, Laode Muhamad Fathun ${ }^{1}$ \\ ${ }^{1}$ Department of International Relations, Universitas Pembangunan Nasional Veteran Jakarta, 12450, Indonesia
}

Article Info

Received: May 01, 2021

Revised: Jul 14, 2021

Published: Jul 31, 2021

Keywords:

Conflict; Iran; Proxy

War; Regional Security

Correspondent:

\section{Hino Samuel Jose}

Department of International

Relations, Universitas

Pembangunan Nasional

Veteran Jakarta.

\section{Email:}

abrahamhinosamueljose@up nvj.ac.id

How to Cite:

Jose, H. S. \& Fathun, L. M. (2021). US - Iran Proxy War in Middle East Under Trump Administration. Journal of Political Issues. 3(1); 36-48. https://doi.org/10.33019/jpi.v 3i1.45

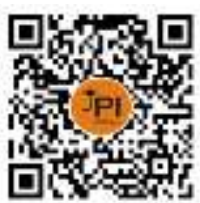

DOI:

https://doi.org/10.33019/jpi.v 3i1.45

\section{Licence:}

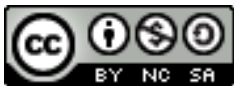

Attribution-NonCommercialShareAlike 4.0 International (CC- BY-NC-SA 4.0)

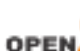

ACCES:

\begin{abstract}
Abstract The heated bilateral relation between Iran and the United States has brought the middle east into another level of problem. The divided geopolitical and regional interest of both countries has led to several and many multidimensional issues, ranging from political, security, and even to economic ones. This article discussed the Iran - US tension on their proxy conflict in the Middle East. This article employs the Regional Security Complex Theory to construct the events related to both states' proxy conflicts. The polarized region for sure has drawn another line that seems to be more complexed for both countries to achieve mutual understanding and continued peacebuilding. The US withdrawal from JCPOA, killing of Soleimani, and Saudi Arabia - Iran Yemen proxy war exacerbated the status quo. This article perceived that the intertwined issues show how the traditional thought of security should be redefined as both countries try to gain bargaining power. Especially with Iran that was hindered very much by sanctions and embargo placed by the US. This article discusses many important issues on Iran, US, and Saudi Arabia involvement and their correlated dynamics within the UN. This article analyzed Trump's leadership style in the Middle East and its implication from the proxy war to the Middle East security architecture.
\end{abstract}

\section{About Authors:}

Hino Samuel Jose, is a penultimate year undergraduate of International Relations, Faculty of Social and Political Science, Universitas Pembangunan Nasional Veteran Jakarta. He is minoring in International Security and Global Development studies.

Laode Muhamad Fathun, is currently a lecturer at the Department of International Relations, Faculty of Social and Political Science, Universitas Pembangunan Nasional Veteran Jakarta. He earned his master's degree in International Relations from Universitas Muhammadiyah Yogyakarta. 


\section{INTRODUCTION}

The heightened tension between Iran and United States has been started since both countries severed their diplomatic relations back in 1979, and the bilateral affairs of both countries are being conducted unofficially between protectorates. Back in 2013, during Iranian President Rouhani's visit to the US, he had a 15-minutes call with President Obama during the momentum of UN General Assembly 2013 (Roberts \& Borger, 2013). This short bilateral call may seem to be a simple diplomatic courtesy, but meant a lot between US-Iran tension where the two countries were seeing positive prospects in Iran's nuclear agenda. Both countries, in general, have always been the center of attention in the Middle East regional security discourses owing to their self-interest and power balancing contestations (Dunn, 2007). In a more neoliberalist view, both countries are also the center of attention when it comes to multilateral dialogue in non-proliferation agenda, where US diplomatic representatives repeatedly blame Iran. The UN-led sanctions, plutonium scrutiny, and Iran's deviation from the agreed security norms are also the main institutional agenda that is utilized by the US to counter Iran (Brzezinski, 2016).

The US presence in Iran and the Middle East architecture as a whole seems to be struggling on their quest to balance power and counterweigh Iran, considering the rising conservatism after the secular Shah Pahlevi was thrown out of power (Nakhavali, 2013). The Khomeini dynasty claimed power against the western powers to reverse its implications within the Iranian society. The United States indeed partaking in the power competition and geopolitical contest against Iran and its allies, while also at the same time being participated by many US' allies. The US indeed has been receiving great threats from Iran nuclear's ambition and its revolutionary leadership which labeled the US as the "great satan" (Yeganeh, 2011).

Following the movements made by Khomeini, the US followed suit with a series of sanctions and embargo, and a new "dual containment policy" (Mirhosseini, 2014). The containment policy was targeted to trigger internal resistance movement to trigger the Iranians in toppling their leader, then a rapprochement with the western power will follow suit. The US is quite optimistic with this approach as their winning on the Gulf War as the Gulf Cooperation Council (GCC) is willing to cooperate with the US, while also participating in negotiating securitization policies with the US (El-Katiri, 2014).

This article discussed the under-discussed issues of US-Iran relations, particularly the issue of proxy wars between both states that were understudied (Rauta, 2018). Proxy warfare is the feasible way of confronting their opponents while also hiding from the risk of violating international law exacerbating a direct conflict that may lead to another World War 3. According to Mumford (2013), proxy warfare is also useful to cause enough geopolitical shift and exploiting conflicts to favor one or more actor(s). and in that sense, it's the goal of the US and Iran is racing to one another for total regional security control and advancing their geostrategy over their economic/ political interests towards the regimes in the Middle East and the Gulf.

According to Basundoro (2020) proxy war in the Middle East is about bandwagoning of allies and balancing efforts in a very systemic rivalry to maximalize the achievement of regional dominant power amid the limited capacity to be a global hegemon. Countries like Yemen, Iraq, and Syria are often depicted as the key areas of Middle East proxy war to actualize each states' influence and extensive external balancing (Ekşi, 2017). The author suggests that it is amazing to see how Iran's domestic ambition can be manifested into their regional foreign policy in such an enormous manifestation. The contemporary proxy war between the major power and emerging power in the Middle East and the Gulf can be seen as a strong signal that uncertainty and civil wars becoming intertwined with external intervention, and countries becoming their proxies alongside armed non-state factions (Basundoro, 2020). 
This paper wishes to focus on their proxy war in the Middle East and the Gulf regional security architecture, about the increased tension ever since President Trump acquired the US Presidency in 2016. Coercive politics exercised by the US and its allies towards Iran does convey a logical causality with the increasing proxy war in the Middle East involving the Sunni versus Shia factions, or US-controlled versus Iran-led proxies. The stringent actions covering social, political, economic, and military dimensions are the key repressive measure to press Iran's nuclear ambition (Sauer, 2007). The bilateral conflict between both countries is also escalating after the US urged the International Atomic Energy Agency (IAEA) to investigate the outstanding nuclear issues, followed by the adoption of UN Security Council resolution 1803 that sanctioned Iran. With no-veto thrown, it is safe to say that the US managed to lobby Russia and its allies in the Security Council and compromised on some political deals. However, this deal has also somehow contributed to the proliferation of bilateral escalation between Washington and Tehran, where Iranian foreign policy against the US is drawn as the efforts in between nuclear agreements and its related proponents and critics regarding their nuclear proliferation and regional politics.

\section{RESEARCH METHOD}

This research employs the qualitative analysis of the literature and supporting data gathered through internet-based research. This article discussed the events related to the arguments and explaining them based on the assumption of regional security complex theory. The questions to be discussed in this article are as follows: (1) What are the events and political situation derived from the status quo that led the US and Iran to start their proxy war; and (2) How the US - Iran proxy war impacts the regional security architecture. This article explains the significance of contemporary events from nuclear proliferation, sanctions, and embargo impacts the dynamic in achieving hegemony within the middle east.

\section{THEORETICAL FRAMEWORK}

\section{Regional Security Complex Theory (RSCT)}

According to Barry Buzan, the development of the regional security status quo enables countries within a region to analyze clusters of states' behavioral patterns within and from a regional perspective (Buzan \& Waever, 2003). The complexity of a region's security is what drives the state actor doing their securitization, which means that security interactions are being done because of their immediate neighborhood. This is supported by Walt (1987) that the adjacent threat(s) tend to come because of the intensified securitization from the nearby states. The studies of the RSCT itself gave a new paradigm in the post-cold-war era where the rethinking of traditional securitization context is happening. Copenhagen school is one of the schools of thought that stands out in providing the conceptualization of the security analysis especially in explaining the regional security dynamics (Dadandish \& Kouzehgar, 2010). In regards to this research, Buzan and Waever posit that the global major powers' interests in the Middle East, are regionally-driven and regionally-made (Buzan \& Waever, 2003). RSCT explains the control variable of the actors' aggressive posture in international politics in a more neorealist view (Marsheimer, 2001).

To view it further, the anarchic international system has made state actors consider their geopolitical and geostrategy interests, which ten yields some sort of "regional-based clusters". In which those clusters explain that the security interdependence done between those actors are more intense and complex hence, spilling outside the context even to the global level (Acharya, 2007). Or in other words, creating another proximity of securitization in the larger web by constructing their identities and ideas in the landscape that can impact the outsiders of a particular region (Buzan \& Waever, 2003). In this research, is the Sunni and Shia identity that is the main driver of Iran - Saudi proxy war that drives the US - Iran bilateral proxy wars that are also impacting the international security architecture were 
factions, sponsors, and interests subjects in one Ferris wheel. Commonalities of these identities also at the same time trigger and catalyze regional cooperation in securing their interests against threats.

\section{RESULT AND DISCUSSION}

The Middle East is a region with complex security architecture compared to other regions around the world. The tensions between the western world and the Persian Gulf countries tend to be intense for the last few decades either by multilateral, regional, or bilateral means. The proxy war in the middle east has escalated the tension between each of the conflicting parties and tremendously changed the security architecture along with geopolitical situations which not only are impactful to the region but also towards many political deadlocks within the United Nations as both major powers, namely Russia and the United States keep competing over influence by sustaining the advancement of their proxies within the region ranging from the Israel-Palestine conflict, Yemen Civil War, Iran's nuclear proliferation, and the Situation in Iraq.

The tension within the region has undoubtedly increased the concerns of the international community thus the political competition between Saudi Arabia and Iran has caused tremendous effects which resulted in the current status quo with few failed states within the Middle East geopolitics. The problem in the region started since the Fall of Shah which led to the competition between Saudi Arabia and Iran that has been proliferating the armed proxy war on many fronts namely Syria, Iraq, and Yemen. Since the beginning of the year 2020, a global crisis has encountered the Persian Gulf. Tensions between the United States of America and the Islamic Republic of Iran have escalated, placing the world near the brink of war. With the killing of an American contractor and the killing of a high-ranking Iranian general, both nations are near war, with alliances and coalitions being operated.

It can't be denied that this multidimensional conflict between the US and Iran is also a direct result of the diplomatic failure of JCPOA from laying grounds/ stipulations that don't consider the unprecedented impact of the changing leadership in the US itself. The populist notion coming from Trump that JCPOA is a "decaying and rotten deal" indeed not only impacting their bilateral status quo with Iran but also concerning their western allies like NATO and EU (BBC News, 2018). The increased US support to the Saudis in Yemen, strengthened bilateral brotherhood with Israel, and the 'hot peace relation with Russia became intertwined and subjects to the manifestation of the proxy lense to attain their foreign policy objective. The proxies that are allied with Iran are indeed being used by Iran to resist the overwhelming sanctions and other pressures by the US and its western allies.

In May 2019, four commercial ships from Aramco (an American - Saudi Arabian energy company) sustained damage, the US blamed this on Iran, as part of an alleged proxysabotage plan (Trevithick, 2019). Another attack worsened the conditions as Houthi (rebels supported by Iran) drones attacked Saudi Arabian oil pipelines, leading to the US directly blaming for the Iranian sponsorship before, during, and after the attack (Yee, 2019). The series of attacks launched by Iran against many oil ships in the gulf sea was done to secure their prone sea from US assertion over the oil supply in the Gulf (Katzman, Mcinnis, \& Thomas, 2020). These numerous events will just show how each actor will try to grab their headstart against each other, and the US as the major power will not stop proliferating their sanctions and trust deficit to Iran.

Politically, Iran is perceived as a fanatic and extreme religious country with little-tono democracy and human rights governance dictated by religious "moralism" against a traditional state actor behavioral preferences (Scott, 2000). The US-Iran hostage crisis back then has been absorbed by the international community as the common perception of Iran, 
while Tehran is establishing anti-thesis behavior against the so-called "US' oppression" (Seymour, 2013).

From the middle east perspective, the division of the Sunni-majority and Shiamajority states became an important factor that splits the proxies and security dynamics within the regional architecture. However, the interesting point is that most of the factions who are fought by the US are Sunni (ISIS, Al-Qaeda, etc), which means that the US is doing Iran's work in eliminating their Sunni enemies within the region as Iran backs Shia factions (Hussain, 2015). This division also goes hand in hand with the historical and recent political and security competition done by Saudi Arabia versus Iran in Yemen and several other issues. With Iran backed by Russia, the contender of the US enemy, and Saudi Arabia backed by the US - plus the same stance of Israel with Saudi against Iran made the sectarian conflicts transitioned to the nuclear and security conflict (Nuruzzaman, 2012).

The major recent update sparked another focal notion that seems to be more relevant to this discourse. President Trump authorized a drone strike in Baghdad International Airport which killed Iran's second in command General Qassem Soleimani, the general of Iran's elite Quds force. The US justified the killing by arguing that Soleimaini and the Revolutionary Guard presented a terrorist threat to US diplomatic personnel in the region. Iran vowed for a "hard revenge" following the attack that killed Soleimaini. Following the killing, the United States embassy in Iraq was under siege after thousands of protestors chanting "Death to America" as they protested the US for killing Soleimani. This has escalated the status quo and even many of the states were thinking that the US and Iran might go into an "all-out" war following the offensive unilateral statement made by Khomeini and Trump.

\section{United States, Saudi Arabia, and Israel Versus Iran}

The contradicting political rhetoric between Saudi Arabia and Iran remains high as the subsequent events preceding the temporary 2017 diplomatic crisis of Qatar versus the rest of the Sunni-majority middle eastern countries (Wintour, 2017). The GCC was divided not merely because of the alleged sponsorship from Qatar towards the violent Islamist groups that were pro to Iran, but also because Riyadh wants to preserve their cohesive supports to the Jaysh al-Islam faction in Damascus (Wahyuni \& Baharuddin, 2017). Saudi Arabia

US seized the opportunity where they use Saudi Arabia as their third party in opposing Iran, particularly in Yemen where the US is supplying tremendous weapons for Saudi's fighter jets. The proxy war in Yemen became prominent to be discussed at the multilateral level when the Saudi-led coalition starting the strikes against Houthis with the Operation "Decisive Storm" to restore the Hadi's government into power while also pressing back the threats from Iran-backed ANSAs, Saudi Arabia kept striking Houthis in which they had the role to determine the proceedings of the conflict since all of the warring factions were controlled by either country in the domain of proxy war in the Yemen Civil War crisis (Baron \& AlHamdani, 2019).

Yemen's case was condemned by Amnesty International as the humanitarian crisis within the country flourish, especially with the public community knowing the US will not stop their support to Saudi Arabia until Iran is running out of fuel in backing the Houthis. Foreign countries backing the Houthis rebel has committed several war crimes and breaches of the international law by continuing to bombard and shelled civilian settlements and injuring people by launching multiple missiles, mortars, and destroying public facilities thus damaging vital objects such as schools, hospitals, and multiple infrastructures as discovered by the Amnesty International since the beginning of the conflict in 2015 (Amnesty International, 2019). Lee (2020) argued that the proxy war in Yemen has caused more than 400 killed a month either by the exchange of fire or by unexploded shells.

Saudi Arabia is perceived to be the major power in the conflict, with Al-Hadi relying on it. Restrictions over the essential needs of the population are widely disrupted by the 
Saudi-led coalition and the Houthis authorities thus causing further suffering of the people in the crisis. International vessels traveling to the ports have to wait for authorization for a long time thus causing fuel, food, and medical shortages and obstructing clean water and sanitation which is crucial amid the Covid-19 pandemic.

Saudi Arabia and Iran's competition for regional influence has been rough and rocky on its quest. Both countries are now bringing instability to the Middle East regional security with their increased proxy war and contradicting strategies that are scaling up over time (Smith, 2016). A previous study argued that the region is being fought by both powers, where Iran is standing with their technocratic government in bringing total Islam rule against the Sunni regional powers led by Saudi Arabia, and directly contesting in Yemen (Moin, 1999). The issue also persists while both countries are also contesting in distributing their political influence over the regional soft power theater to create a "purist" version of Shia (Dai, 2018). This is also being influenced by the direct US-Iran standoff in Syria under Al-Assad to counter US military advancement through the work of ISIS, where Iran plays a significant role in funding the faction and shaping war tactics (Steenkamp, 2017).

In the post-Iraq 2003 war, the regional shift between Iran and Saudi intensified, with the Iranian struggle to outnumber Saudi's military power backed by the US, we can see that Iran remains far outclassed and have yet to reach quantitative advantage (Grare, 2007). With Saudi and Iran contesting in a sectarian spectrum, their political balance will remain as a zero-sum game (Wehrey, 2011). Both Riyadh and Tehran are concerning their approach to solidify relations with their actual and potential proxies that are equipable with their sectarian division (Naghizadeh, 2019). To relate this with the US - Iran context, Trump was supporting Saudi Arabia with arms and intelligence to Saudi Arabia in countering Iran's direct intervention in Yemen, as Saudi wishes to secure their border before spilling counterproductive effects to the country. Saudi perceived that Al-Hadi's regime security is far more important rather than the people's protection (Ahmed, 2019). This was also the case of the US where the complex Saudi-led coalition is also aligned with other proxies that are striving for a political balance under the Hadi's government, as it is also the recognized ruler of Yemen by the UN. The US backs up Saudi through their position at the UN Security Council to create a favorable climate, while the US is counterbalancing Iran's factions by US offensives in the Middle East to degrade every Tehran-aligned proxies.

Moving on, ISIS is a non-state enemy of the US, Israel, and Saudi Arabia and many already put their suspicion towards ISIS that has been driven by Assad that is a strong ally of Iran. The regeneration of these new fighters is perpetrating Saudi's homeland security and their political intervention, and the US is also taking a hardline stance against it by their operation in Syria, although Trump's decision to withdraw US troops gradually from Syria must've been concerned by Riyadh. The emergence of ISIS draws 2 parallel lines, either Saudi should unite the Gulf countries against ISIS to prevent Iran's momentum to gain regional power, or should they focus on circumventing both issues with the current grey attention of the Gulf leaders (Berti \& Guzansky, 2014). Habitat Al-Nusra and ISIS are both Saudi's attention in advancing GCC's and Saudi's comparative advantage against Iran amidst their geopolitical inferiority (Berti \& Guzansky, 2014; Kamrullah, 2017; Qurtuby \& Aldamer, 2020). This is a key narrative because the Gulf countries are Saudi's only front yard against Tehran, and the Gulf is the key connectivity between Saudi and the rest of the AsiaPacific on their oil trade.

Under the Trump administration, US-Saudi relation has been enforced by the US' unilateral ambition to counter all Iranian foreign policy pillars which are anti-western, antizionist, Pan-Islamist, anti-Sunni, and Pro-resistance movement through a hardline populist stance of a conservatism leader (Beck, 2019). With the rough geopolitical road to be driven on, the Trump administration is still confident that getting out of the so-called "flawed deal of the century" can support US efforts in circumventing Iran's firm stance in inserting external 
aspects as part of re-negotiation substance (Rahman, 2020). The author suggests that as long as Israel is still being taken care of by the US, Iran will never regress from its ambition, and would wish for a larger influence against the US major bulwark in the region, Saudi Arabia and Israel.

\section{JCPOA and Proxy War in the Region}

After the US was leaving the JCPOA, the relation between Iran and the US is worsened, even today. The United States withdrew from the JCPOA in May 2018 after Donald Trump signed a Presidential Memorandum and imposed heavier sanctions on Iran. Many of the UN member states within the UN Security Council criticized the withdrawal of the US from the JCPOA as the deal itself was assessed by the IAEA to be effective and was conducted by the Iranian government with full compliance. Trump argued that the deal did nothing to limit Iran's ballistic missile program or its regional aggressions. Following the withdrawal, the Iranian currency value dropped significantly which led to strong anti-US sentiment in the government of Iran. The deal was still preserved with the European Union covering the spots left behind by the US, the rest of the P5+1 states managed to eased some diplomatic uncertainty of the JCPOA. However, the reality can't be avoided because the US does hold an important position that determines the fate of Iran's economic fallout caused by the sanctions. Ever since the US left JCPOA, the deal is nothing but leaving tremendous uncertainty on the Iran nuclear proliferation as multilateral forums tend to be hopeless for any inclusive political dialogue (Bayoumy \& Love, 2018).

The moment the US left JCPOA under Trump's order, Iran realized the glimpse of what's worse to come, starting from the assassination of Soleimani, several heavy sanctions which crippled Iran's response to Covid-19, and weakened trade and development with the other countries. Historically and politically speaking, the increased trust deficit and lack of collaboration between the US and Iran hampered the progress of peacebuilding and stability in the Persian Gulf. The establishment of JCPOA as a tangible confidence-building measure to support peacebuilding somehow became stagnant as the commitment and lack of compliance from Iran were perceived by the United States as a threat and indicator that Iran would not compromise. In regards to nuclear development, Israel also repeatedly rejects to bound themselves to the JCPOA and even Netanyahu is still promoting anti-Iran nuclear agenda during his speech at the plenary session of the UN General Assembly. Israel may not be playing explicitly alongside other Arab countries against Iran due to Palestine, but covertly speaking they are cooperating ever since the 2019 Warsaw Conference (Totten, 2016).

To briefly digress from the US-Israel partnership, this is one of the big reasons so many hardliners in Iran oppose a nuclear agreement. Many Iranian hardliners, with skepticism of Western power and, in some cases, a disdain for Israel, have worked to derail the agreement, either implicitly or covertly, implying that the two countries will not be able to restore relations (Morgan, 2015). To understand, states' interaction in achieving a solid bargaining stance can be reached if the economic, political, and power modality is presented during the process (Nye, 2010). Another thing, a survey showed that the Saudis are perceiving Iran as larger threats compared to Israel, plus their agenda and affiliated proxies in the middle east either in Syria, Yemen, Iraq, and Lebanon are still aligned in one interest which is to defeat Iran (Totten, 2016). However, still in the public sphere, Saudi is still reluctant to go official with their regional security cooperation with Israel although its neighbors already established 4 peace deals under the Abrahamic accord that signaled a good hope for Middle East peacemaking (Bassist, 2021).

JCPOA is indeed problematic, because when the US withdraws from the treaty - their representative stated that JCPOA is non-binding, while the Iranian delegation stated otherwise. The unclear legal claim and prejudices exercised by both countries through their unilateral stance have caused the dispute settlement mechanism in JCPOA flawed and useless 
to prevent the stagnancy after the US left the treaty (Ramsey, 2016). Under the Trump administration, the US always rejected the IAEA verification that concludes with "Iran complying all standards, and the nuclear is developed for peaceful purposes".

The whole discourse regarding JCPOA may not understand the whole unilateral reason of US withdrawal and "slander" against IAEA. The author suggests that the US withdrawal is also the key trigger of Iran's usage of proxies in the Middle East because they are pretty much struggling in fulfilling their economic development goals. The conflictual nature of this JCPOA discourse made the US becoming more skeptical whether Iran is implying compliance or deceiving IAEA and the international community. These constructed ideas are perceived by the US to be answered with sanctions and embargoes that can break the last-standing Iranian axis and forcing them to play by the book (el Khalfi, 2020). Iran as a rational actor securitize their focal advantages to nag out US' security in the region through its proxies, whilst thwarting the threats by US' allies like Israel and Saudi on many fronts and dimensions - all to secure their nuclear ambition and to counterweigh Israel as the major nuclear power within the region.

\section{US - Iran on the United Nations}

Historically, Iran is also being pressed by the UN with the UN through the Security Council resolution 1929 in 2010 that called for the establishment of a UN panel of experts to assist Iran's UN sanction committee in handling the monitoring, assessment, and reaffirmed the previous UN resolutions (namely resolution 1887 and 1540) regarding disarmament and nonproliferation. The resolution was 14 pages long and stipulated all working mechanisms, sanctions provisions, and also reaffirming that Iran should comply with its nuclear program limitation as recommended by the IAEA.

United Nations Security Council, is also being used by the actors like the US to flare up their war with Iran. The US has imposed numerous economic and political sanctions to press the regime as the United States demands Iran to stop their alleged nuclear program (in concern with the generation of nuclear weapons). The rejection of the United States towards Iran's nuclear program also caused the involved parties in the Security Council to adjust their positions and relations regarding the region. The unavoidable clash has drawn the line where the United States agenda and Iran's ambition against it have done a tremendous impact in hampering the multilateral solutions adopted all over time.

The worsening of relations between the US and Iran came into the spotlight in 2015 when the US alongside the Security Council and Iran implemented the Joint Comprehensive Plan of Action as a measure to dismantle Iran's nuclear project in exchange for the lifting of sanctions. US Secretary of State Mike Pompeo stated in the UNSC Virtual Meeting on July 1st, 2020 that "...the United States realized the flawed nuclear deal and we justify our withdrawal from the nuclear deal as it was negotiated poorly by the previous administration". Relations tend to improve when the two countries have overlapping goals, such as repelling Sunni militants during the Iraq War and the intervention against ISIS although the two sides manage to clash against each other for instance in Iraq, Syria, and the Question of PalestineIsrael Conflict agendas.

The UN Security Council resolution 2231 was a key hope in stabilizing the long-held rivalry, however, the Trump administration also carried out multiple sanctions that have been questioned by many member states in the UN. A previous legal study made it clear that the US should be consistent with its commitment to JCPOA and their withdrawal is illegal at some particular aspects of international law (Valerio Jovan, 2021). Politically, these contrary movements made by the US under the Trump administration will shed some counterproductive implications to US policies in the middle east seen by the international community, especially the US has been boasting about Iran as a global terrorist. Trump's foreign policy is assertive, and many statements have been thrown frontally on many 
occasions within the UNGA plenary, UN Security Council open debate, and press meetings.

The UN however doesn't have any adequate mechanism that can enforce international regime to de-escalate tensions caused by the state actors. The proxy wars and skirmishes among factions has been escalating US' intervention to do more bombings and other unilateral armed intervention that has been causing casualities. Numerous UN Security Council resolution adopted on the question of Iran also caused Tehran to be reluctant and keep increasing their megaphone diplomacy against the western powers. A previous study concluded that the UN Security Council sanctions on Iran aren't modest in nature and the red lines drawn from the sanction couldn't force Tehran to comply but to resist (Asadi, 2015). The sanctions also caused Iran to cope by reducing vulnerability on prone sectors while emphasizing a resistive economic style to counterweigh political pressure using illegal means. On the context of proxy war, until now there is no discussion regarding the proliferation of non-state actors nor any unilateral statement regarding it. Hence, this discourse in unilateral level is still vague as the author suggest this in a more strategic overview rather than single identification of proxies and their linkage.

\section{CONCLUSION}

The increased tension of the US and Iran will keep being proliferated until the balance of power is reached. However, the setbacks that overweigh the advantages of diplomacy seem to give the perception that this regional conflict will ends. The United States made Saudi Arabia their proxy in Yemen, we can see that Saudi Arabia and Iran play a specific role in the Gulf security architecture. This notion is linked to the Yemen Civil War. Saudi Arabia as one of the countries with tremendous different political and religious stances with Saudi Arabia did involve and had the role to determine the proceedings of the conflict since all of the warring factions were controlled by either of both countries in the domain of proxy war in the Yemen Civil War crisis.

Iran will remain as the US main enemy in the middle east, prospect of changes can be expected if Washington under the Biden administration can entertain a more sophisticated and structured alliance-building. Indeed a collaborative steps may be taken to secure the US's interest in Iran and the Gulf as a whole, however it shouldn't give Iran too much leniency to prevent Tehran from acquiring a larger headstart against US politics. Tehran should also entertain a more descriptive deal that can allow the nuclear disarmament to happen under strictest confidence. The US under Trump administration has always been very isolationist, hence the induction of political arrangements should've been carefully crafted in ensuring that Iran will comply to IAEA monitoring and satisfy the mutual interest of P5+1 states. However, with the current state of global politics, US may not put Iran as their center of foreign policy gravity due to the rising contestation with China. The Russian-Iranian bilateral relation would be scrutinized pertaining to the increasing Washington's interest in moving up again with NATO as an old ally after Trump isolates US from global security cooperation.

Outside of Yemen, the US uses Israel as their proxy, where Israel is also involved in informal cooperation with other Middle East countries. We can see that Iran is somewhat the catalyst of the Abrahamic accords. Because without Iran, those 4 Arab States will be attracted to establish their diplomatic relation with Israel that was mediated by Trump. Several implications should be considered. First, Iran and the US should reflect on Israel, Qatar, and other countries that are still putting their sponsorship towards the ongoing conflict in the middle east such as Yemen and Syria. These countries became the major driver of Iran and the US's main political agenda. Second, Israel will become a major player if they managed to succeed in the diplomatic relation establishment with the rest of Arab countries as it will trigger division within the GCC - that might weaken Iran's position and leverage within the GCC. Lastly, the Trump administration's support to key players like Saudi and Israel is based on identities and political economy cooperation over the middle east. Therefore, with the new 
Biden administration, it should be concerned regarding what's next for the middle east after Trump's assertive foreign policy in defending their allies against Iran through bilateral manner.

\section{REFERENCES}

Acharya, A. (2007). The Emerging Regional Architecture of World Politics. World Politics, 59(4), 629-652. https://doi.org/10.1353/wp.2008.0000

Ahmed, N. (2019). Yemeni Civil War: Causes, Consequences And Prospects. JDP (Jurnal Dinamika Pemerintahan), 2(2), 82-91. https://doi.org/10.36341/jdp.v2i2.943

Amnesty International. (2019). Review of human rights in the Middle East and North Africa. Retrieved July 8, 2021, from https://www.amnesty.org/en/latest/research/2019/02/human-rights-in-the-middle-eastand-north-africa-2018/

Asadi, T. (2015). On the Effectiveness of UN Security Council Sanctions: HSE Approach to the Case of Iran. Actual Problems of Economics: Scientific Economic Journal, $11(173)$, $21-31$. https://www.researchgate.net/publication/291699416_On_the_effectiveness_of_UN_s ecurity_council_sanctions_HSE_approach_to_the_case_of_Iran

Baron, A., \& Al-Hamdani, R. (2019, December 10). The "Proxy War" Prism on Yemen. New America. https://www.newamerica.org/international-security/reports/the-proxy-warprism-on-yemen/

Bassist, R. (2021, March 29). Chances for Israeli alliance with Saudis against Iran fading. Al-Monitor: The Pulse of the Middle East. https://www.almonitor.com/originals/2021/03/chances-israeli-alliance-saudis-against-iran-fading

Basundoro, A. F. (2020). Perang Proksi Kontemporer Arab Saudi-Iran Sebagai Bentuk Turbulensi Timur Tengah: Sebuah Analisis Geopolitik. Jurnal Penelitian Politik, 17(1), 1-16. https://doi.org/10.14203/jpp.v17i1.847

Bayoumy, Y. B. L., \& Love, B. (2018, May 10). Europeans work to save Iran deal, and business, after Trump pulls out. U.S. https://www.reuters.com/article/us-irannuclear/europeans-work-to-save-iran-deal-and-business-after-trump-pulls-outidUSKBN1I90D6

BBC News. (2018, May 9). Iran nuclear deal: Trump pulls US out in break with Europe allies. https://www.bbc.com/news/world-us-canada-44045957

Beck, M. (2019). US Middle East Policy Shift: Trump's Administration Divergency. RUDN Journal of Public Administration, 6(4), 296-311. https://doi.org/10.22363/2312-83132019-6-4-296-311

Berti, B., \& Guzansky, Y. (2014). Saudi Arabia's Foreign Policy on Iran and the Proxy War in Syria: Toward a New Chapter? Israel Journal of Foreign Affairs, 8(3), 25-34. https://doi.org/10.1080/23739770.2014.11446600 
Brzezinski, Z. (2016, February 10). From Hope to Audacity Appraising Obama's Foreign Policy. Foreign Affairs. https://www.foreignaffairs.com/articles/2009-12-11/hopeaudacity

Buzan, B., \& Waever, O. (2003). Regions and Powers: The Structure of International Society. Cambridge: The Press Syndicate of the University of Cambridge.

Dadandish, P., \& Kouzehgar, K. J. (2010). A Critical Study of Regional Security Complex Theory by Using the Security Environment of South Caucasus. Rahbord, 19(56), 73 107. https://www.sid.ir/en/Journal/ViewPaper.aspx?ID=188895

Dai, H. (2018, August 31). Middle Eastern Interventions in Africa: Tehran's Extensive Soft Power. Middle East Forum. https://www.meforum.org/7254/middle-easterninterventions-in-africa-tehran

Dunn, D. H. (2007). 'Real men want to go to Tehran': Bush, pre-emption and the Iranian nuclear challenge. International Affairs, 83(1), 19-38. https://doi.org/10.1111/j.14682346.2007.00601.x

Ekşi, M. (2017). Regional Hegemony Quests in the Middle East from the Balance of Power System to the Balance of Proxy Wars: Turkey as Balancing Power for the Iran - Saudi Rivalry. Gazi Akademik Bakış, 11(21), 133-156. https://doi.org/10.19060/gav.379597

El-Katiri, M. (2014). United States-Gulf Cooperation Council Security Cooperation in A Multipolar World. Carlisle: US Army War College Press. http://www.jstor.org/stable/resrep11893

el Khalfi, M. A. (2020). AGREEMENT ON THE JOINT COMPREHENSIVE PLAN OF ACTION (JCPOA) BETWEEN IRAN AND THE UNITED STATES. Jurnal Pembaharuan Hukum, 7(2), 183. https://doi.org/10.26532/jph.v7i2.11296

Grare, F. (2007). The Evolution of Sectarian Conflicts in Pakistan and the Ever-Changing Face of Islamic Violence. South Asia: Journal of South Asian Studies, 30(1), 127143. https://doi.org/10.1080/00856400701264068

Hussain, N. (2015). US-Iran Relations: Issues, Challenges and Prospects. Policy Perspectives, 12(2), 29-47. https://doi.org/10.13169/polipers.12.2.0029

Kamrullah, M. R. N. (2017). Peran Jabhat Al-Nusra dalam Memberikan Tantangan terhadap Kebijakan Amerika Serikat Mendukung Kelompok Oposisi pada Konflik Bersenjata di Suriah. Global: Jurnal Politik Internasional, 19(2), 77. https://doi.org/10.7454/global.v19i2.287

Katzman, K., Mcinnis, K., \& Thomas, C. (2020, May 8). U.S.-Iran Conflict and Implications for U.S. Policy. CRS Reports. https://www.everycrsreport.com/reports/R45795.html

Lee, L. (2020). The Yemen crisis and civil society: surviving the despite odds. Humanitarian Exchange, https://odihpn.org/magazine/yemen-crisis-civil-society/

Marsheimer, J. (2001). The Tragedy of Great Power Politics. New York: W. W. Norton. 
Mirhosseini, S. M. (2014). Evolution of Dual Containment Policy (the Policy of Clinton's Administration - Clinton's Doctrine) in the Persian Gulf. Sociology and Anthropology, 2(3), 106-112. https://doi.org/10.13189/sa.2014.020305

Moin, B. (1999). Life of the Ayatollah. New York: Thomas Dunne Books.

Morgan, C. (2015). US - Iran Relations: A History of Covert Action and a Promising Future. The Cohen Journal, 2(1). Diambil kembali from https://digitalcommons.library.umaine.edu/tcj/vol2/iss1/1

Mumford, A. (2013). Proxy Warfare: War and Conflict in the Modern World. Cambridge: Polity Press.

Naghizadeh, M. (2019). Rivalry Through Proxies: How Iran and Saudi Arabia Compete For Regional Influence. St Antony's International Review, 137-153. https://www.researchgate.net/publication/335977824_Rivalry_through_proxies_How_I ran_and_Saudi_Arabia_compete_for_regional_influence_-

_St_Antony's_International_Review

Nakhavali, M. (2013). Diplomatic, Consular and Political Relations Between Iran and United $\begin{array}{lllll}\text { States. } & \text { European } & \text { Scientific } & \text { Journal, } & 9(14),\end{array}$ https://eujournal.org/index.php/esj/article/view/1069/1103

Nuruzzaman, M. (2012). Conflicts between Iran and the Gulf Arab States: An Economic Evaluation. Strategic Analysis, 36(4), 542-553. https://doi.org/10.1080/09700161.2012.689512

Nye, J. (2010, June 14). East Asian Security: The Case for Deep Engagement. Foreign Affairs. https://www.foreignaffairs.com/articles/asia/1995-07-01/east-asian-securitycase-deep-engagement

Qurtuby, S. A., \& Aldamer, S. (2020). Terrorism and Counterterrorism in Saudi Arabia. Contemporary Review of the Middle East, 8(1), 56-76. https://doi.org/10.1177/2347798920976286

Rahman, M. (2020). CURRENT PHENOMENON TENSION OF THE UNITED STATES AND IRAN IN THE MIDDLE EAST. Journal of Islamic World and Politics, 4(1), 31-47. https://doi.org/10.18196/jiwp.4143

Ramsey, M. D. (2016). Evading the Treaty Power?: The Constitutionality of Nonbinding Agreements. FIU Law Review, 11(2). https://doi.org/10.25148/lawrev.11.2.9

Rauta, V. (2018). A structural-relational analysis of party dynamics in proxy wars. International Relations, 32(4), 449-467. https://doi.org/10.1177/0047117818802436

Roberts, D., \& Borger, J. (2017, December 1). Obama holds historic phone call with Rouhani and hints at end to sanctions. The Guardian. https://www.theguardian.com/world/2013/sep/27/obama-phone-call-iranian-presidentrouhani

Sauer, T. (2007). Coercive Diplomacy by the EU: The Case of Iran. The Hague: Netherlands Institute of International Relations 'Clingendael'. 
Scott, C. V. (2000). Bound for Glory: The Hostage Crisis as Captivity Narrative in Iran. International Studies Quarterly, 44(1), 177-188. https://doi.org/10.1111/00208833.00153

Seymour, L. J. M. (2013). Let's Bullshit! Arguing, Bargaining and Dissembling Over Darfur. SSRN Electronic Journal, 20(3). https://doi.org/10.2139/ssrn.2386522

Smith, J. B. (2016, January 5). Former U.S. Ambassador: What the Saudi Arabia-Iran Conflict Means for Stability. Time. https://time.com/4167026/saudi-arabia-iranconflict-and-stability/

Steenkamp, C. (2017). The Crime-Conflict Nexus and the Civil War in Syria. Stability: International Journal of Security and Development, 6(1). https://doi.org/10.5334/sta.522

Totten, M. J. (2016). The New Arab-Israeli Alliance. World Affairs, 179(2), 28-36. https://doi.org/10.1177/0043820016673779

Trevithick, J. (2019, May 14). U.S. Government Claims Iran Is Behind Attacks On Oil Tankers, But Has Yet To Show Evidence. The Drive. https://www.thedrive.com/thewar-zone/27992/u-s-government-claims-iran-is-behind-attacks-on-oil-tankers-buthas-yet-to-show-evidence

Valerio Jovan, C. (2021). THE UNITED STATES UNILATERAL WITHDRAWAL FROM THE RESTRICTIONS OF IRAN'S NUCLEAR PROGRAM IN JCPOA 2015 UNDER INTERNATIONAL LAW. Padjadjaran Journal of International Law, 4(2), 247-264. https://doi.org/10.23920/pjil.v4i2.414

Wahyuni, S., \& Baharuddin, S. S. (2017). The Impact of GCC Boycott on Qatar Foreign $\begin{array}{llll}\text { Policy. Jurnal Transformasi } & \text { Global, }\end{array}$ https://transformasiglobal.ub.ac.id/index.php/trans/article/view/71

Walt, S. M. (1987). Origins of Alliance. Ithaca: Cornell University Press.

Wehrey, F. (2011). Uprisings Jolt the Saudi-Iranian Rivalry. Current History, 110(740), 352357. https://doi.org/10.1525/curh.2011.110.740.352

Wintour, P. (2017, November 28). Qatar diplomatic crisis - what you need to know. The Guardian. https://www.theguardian.com/world/2017/jun/05/qatar-diplomatic-crisiswhat-you-need-to-know

Yee, V. (2019, May 15). Yemen's Houthi Rebels Attack Saudi Oil Facilities, Escalating Tensions in Gulf. The New York Times. https://www.nytimes.com/2019/05/14/world/middleeast/saudi-oil-attack.html

Yeganeh, H. (2011). The "Great Satan" talks with the "Evil." International Journal of Conflict Management, 22(3), 219-238. https://doi.org/10.1108/10444061111152946 